\title{
RANGE EXTENSION OF THE BLUE WILDEBEEST
}

\author{
F. C. ELOFF, D.Sc. \\ (Department of Zoology, University Pretoria)
}

Animal communities are not fixed in their distribution but change continuously with changes in environmental conditions, population density and human activities. Very little is known about the range changes of African game animals, either under natural conditions or within enclosed areas. This may be partly due to the fact that the slow, tedious process of dispersal has, in contrast with the spectacular migrations of some species, failed to arouse any particular interest amongst wildlife biologists and hence little has been recorded on the range changes of African mammals.

The concept of range extension is of course sometimes difficult to apply to the truly migrating or nomadic species. Yet, where permanent range extension could be demonsirated it certainly warrants attention, along with all the facors usually involved in dispersal, such as rate of dispersal, habitat selection, environmental resistance at the edge of its range, social con'act with species not encountered within its original range, reaction of other species, and the result of competition, if any, on the community as a whole.

There are authentic cases where certain mammal species have, over a number of years, gradually and consistently expanded their range. Apart from ihis fact, however, very little is known about the impact of this extension on the vegetational environment and associated animal species.

One such case is the inyala. When the Kruger National Park was established in 1926, inyalas did not occur in the park. The first individuals were detected in the northernmost part of the present Kruger National Park in 1929 and from here the inyala gradually extended its range southwards. Yet its dispersal did not always go very smoothly and in many ways it appears to have been an irregular process, characterised by numerous advances and withdrawals.

The history of the elephant, the giraffe, the eland and perhaps other species in the Kruger National Park might also provide interesting examples of the rate of dispersal and the influence of limiting factors and other phenomena mentioned above.

Early information on the disiribution of the blue wildebeest in the Kalahari Gemsbok Park is difficult to obtain but it is known that when the park was established in 1931 blue wildebeest only occurred in the Nossob River and adjoining areas, mainly in the norihern part of the park. These 
herds migrated annually, moving between the park and Bechuanaland at foirly regular intervals, Bechuanaland being their wintering quarters. As no wildebeest were found in the Auob river, with the possible exception of a few roving individuals, the park could not claim to have a permanent blue wildebeest population at the time of its establishment.

In 1948, however, soon after permanent water was made available at the so-called 16th borehole in the Auob River, about 12 miles from Mata Mata, a large number of blue wildebeest moved into this area and when the main herd left after staying there for some time, 46 individuals remained behind. They never emigrated again and formed the nucleus of the present population of several hundred individuals found in the Auob River.

When the author first visited the Park in 1957 the total blue wildebeest population inhabiting the Avob River was still restricted to a relaively small area in the upper part of the river, the whole range covering a distance of approximately 25 miles along the river bed and the dunes adjoining the iver. Over a period of 10 years therefore this population hardly extended its range, although the numbers increased within that period from 46 to several hundred.

In 1958 grazing conditions in that area were extremely bad. Due to low rainfall and probably also to overgrazing, the bed of the Auob was almost bare. Even water was scarce; due to the heavy concentration of game at this point the demand exceeded the supply. Only a few miles lower down in the direction of Twee Riviere, grazing conditions were much better, mainly as a result of some good local rains that had fallen there a few months earlier. If the blue wildebeest therefore migrated only a few miles downwards they would have found much better grazing and plenty of water. Yet they preferred to remain in the overgrazed section around the 16th borehole.

Towards the end of 1959, however, when conditions again became unfavourable, the blue wildebeest wandered about a great deal. Of the total number of about 500 animals which inhabited this area at that time, the majority moved away, only a few remaining behind, the rest dispersing to points as far as 35 miles from the river. They returned after about two months almost immediately after their regular haunts near Mata Mata had a good shower of rain.

From then onwards, perhaps due to population pressure, they gradually extended their range towards Twee Riviere.

The following particulars give an indication of the rate of range expansion, based on regular counts made from 1957 onwards, along the Auob River from Mata Mata to Twee Riviere, a distance of 75 miles. As Mata Mata is situated on the South West African boundary, range expansion is possible in one direction only.

In 1957 the range extended from Mata Mata to a point 30 miles down the river, where a lone bull was observed. 
The main body of the population, however, had not advanced so far, being five miles further back, where two small herds, numbering 8 and 18 respectively, were found.

In 1958 a herd of 30 blue wildebeest were encountered 30 miles from Mata Mata in the Auob. Although no range extension since the previous year could be shown, therefore, the main body of the herd had clearly advanced forward.

In 1959 a herd of 20 wildebeest was seen in the Auob 45 miles from Mata Mata, showing a considerable range expansion on the previous year.

In 1960 a single bull was found 60 miles from Mata Mata and in 1961 the position was still the same, a single bull occurring in more or less the same spot with the vanguard of the main herd some miles back.

In 1962 two lone bulls were observed about 70 miles from Mata Mata, not far from the confluence of ihe Auob and Nossob rivers and, according to the game ranger, a few individuals wandered down the Aoub River right up to Twee Riviere during that year. The dispersal process down the Auob River was therefore completed during 1962.

The various factors that might be involved in range extension is difficult to assess in the present case. Over the period that the range expansion of the blue wildebeest took place environmental conditions did not change, apart from the periodical droughts and occasional floods characteristic of this semi-desert country. No new species were encountered in its invasion of new areas. The animals soon became accustomed to man's presence and, due to the provision of watering points in the Auob River, human activities indeed seemed to have speeded up the process of range expansion. 